(C) Inra/Elsevier, Paris

Original article

\title{
Genetic parameters of spontaneous spring ovulatory activity in Mérinos d'Arles sheep
}

\author{
Eric Hanocq ${ }^{\mathrm{a}}$, Loys Bodin ${ }^{\mathrm{a}}$, Jacques Thimonier ${ }^{\mathrm{b}}$, \\ Jacques Teyssier ${ }^{b}$, Benoit Malpaux ${ }^{c}$, Philippe Chemineau ${ }^{c}$ \\ a Département de génétique animale, Station d'amélioration génétique des animaux, \\ Institut national de la recherche agronomique, 31326 Castanet-Tolosan, France \\ ${ }^{\mathrm{b}}$ Unité de zootechnie méditerranéenne, École nationale supérieure agronomique \\ de Montpellier - Institut national de la recherche agronomique, \\ 34060 Montpellier, France \\ ${ }^{c}$ Neuroendocrinologie sexuelle, Physiologie de la reproduction des mammifères \\ domestiques, Institut national de la recherche agronomique, 37380 Nouzilly, France
}

(Received 23 July 1998; accepted 5 November 1998)

\begin{abstract}
The genetic parameters of spontaneous spring ovulatory activity were investigated in the Mérinos d'Arles breed under the usual pastoral and transhumant management conditions of this breed in southeastern France. Ovulatory activity was determined by assaying the plasma progesterone concentration in two blood samples taken 8-10 days apart. The data set consisted of 1887 ovulatory activity performance measurements in 1995, 1996 and 1997 on 933 ewes, daughters of 176 rams. The effects of the 'physiological status' (hoggets, adult ewes with or without lambing in the previous autumn), age and live weight just before the mating period were found to be highly significant. They were included in the linear animal model and the threshold sire model used to estimate genetic parameters. On average, $27.9 \%$ of ewes exhibited ovulatory activity in April. Age and live weight just before the mating period had a marked positive effect on ovulatory activity. A difference of about 8-9\% was observed between extreme classes for these factors. The heritability and repeatability estimated through the linear model were 0.20 (standard error: 0.04 ) and $0.30(0.07)$, respectively. When using the threshold model, the heritability was 0.37 . These values led us to conclude that a genetic approach for improving spontaneous spring ovulatory activity should be further developed. Nevertheless, further studies are necessary to determine all the implications of such selection. (c) Inra/Elsevier, Paris
\end{abstract}

seasonality / reproduction / genetic parameter / sheep / ovulation

\footnotetext{
* Correspondence and reprints

E-mail: hanocq@germinal.toulouse.inra.fr
} 
Résumé - Paramètres génétiques de l'activité ovulatoire spontanée au printemps dans la race ovine Mérinos d'Arles. Les paramètres génétiques de l'activité ovulatoire spontanée au printemps ont été estimés en race Mérinos d'Arles dans le système d'élevage pastoral traditionnel (transhumance estivale) du sud-est de la France. Le dosage de la progestérone plasmatique dans deux prélèvements sanguins effectués à 8-10 j d'intervalle a permis de déterminer l'activité ovulatoire des brebis. 1887 performances d'activité ovulatoire ont été enregistrées en 1995, 1996 et 1997, sur 933 brebis issues de 176 béliers. Le «statut physiologique» (antenaises, brebis adultes avec ou sans mise bas à l'automne précédent), l'âge et le poids au moment de la lutte des brebis ont des effets très significatifs sur l'activité ovulatoire. Ils ont été pris en compte dans le modèle animal linéaire et le modèle père à seuil utilisés pour estimer les paramètres génétiques. En moyenne, 27,9\% des brebis présentaient une activité ovulatoire en avril. L'âge et le poids au moment de la lutte ont un net effet positif sur l'activité ovulatoire. Une différence de 8-9\% a été observée entre les classes extrêmes pour ces facteurs. L'héritabilité et la répétabilité estimées avec le modèle linéaire sont de 0,20 (erreur standard : 0,04) et de 0,30 $(0,07)$, respectivement. L'héritabilité calculée avec le modèle à seuil est de 0,37 . En conclusion, compte tenu de ces valeurs, l'approche génétique visant à améliorer l'activité ovulatoire spontanée au printemps mérite d'être poursuivie. Néanmoins, d'autres études sont nécessaires pour connaître toutes les implications que supposent une telle sélection. (c) Inra/Elsevier, Paris

saisonnement / reproduction / paramètre génétique / ovin / ovulation

\section{INTRODUCTION}

Most sheep breeds in temperate latitudes are seasonal breeders. Hafez [14] first showed differences in the duration of breeding seasons in British breeds raised in the same location. Sexual activities of females and males are influenced by changes in day length [30]. In temperate zones, the breeding season classically corresponds to the period of decrease in day length, especially in autumn. For economic and management reasons this seasonality may be a handicap for farmers and processing industries. Control of the breeding period is possible in several ways. Hormonal and/or photoperiodic treatments [2,3] are efficient but allow only a partial abolition of seasonality. They may have negative consequences on the future efficiency of reproduction, on its cost and on the image of the product. Bodin et al. [1] showed a lower fertilisation rate, fertility and prolificacy associated with repeated PMSG treatments. The use of the 'ram effect', consisting mainly of an adequate management of the interactions between males and females [27], is also an efficient way of inducing ovulatory activity, but its efficiency may be limited, especially in highly seasonal breeds. For the ram effect, the influences of genetic factors for females and males [28] and environmental factors, such as the depth of the seasonal anestrus [27] or the presence of already cyclic ewes $[26,32]$ has been shown. Moreover, induced oestrous activity may be quickly followed by a return to anestrus [28].

Developing a genetic approach for improving the out-of-season breeding ability of animals (as opposed to the classical breeding season in sheep in temperate latitudes) may be an interesting way of controlling the seasonality of conception. The breeding season is characterised by its duration, its date of onset and its date of cessation. Various authors $[17,24,37,41]$ have mentioned that genes control a part of the existing variability in these traits. Genetic 
differences between breeds and between individuals within a breed have been shown [14]. Dyrmundsson and Adalsteinsson [6] have shown a significant effect associated with a coat-colour gene upon out-of-season sexual activity. Given these results, a genetic approach for controlling the breeding season may be possible.

However, the out-of-season breeding ability is not a trait that is easy to define and to measure. First, for practical reasons, such as interaction with reproduction, cost and workload, the dates of onset and end of the breeding season are difficult to record in a large number of ewes, especially on private farms. Then, if measurements are possible, the expression of out-of-season breeding ability differs according to the criteria used for its measurement and the environmental context in which it is studied. Genetic studies may be based on the performance recorded at various times of the out-of-season mating period. They may consist in detecting ovulatory or oestrous activities and necessitate blood samplings and hormone assays, or heat detection. Depending on the time of the testing and its duration, such measurements make it possible to define characteristics of the breeding season, or those of the seasonal anestrus. Other studies may be based on fertility performance interpreted as a result of the out-of-season breeding ability of the ewes. When detecting heats or measuring fertility, except if males are in the flock all the year round $[5,9]$, joining ewes and rams induces a 'ram effect'. It is then impossible to separate the ewes that are spontaneously ovulating from those responding to the 'ram effect'. Measuring spontaneous ovulatory activity before any attempt at induction of sexual activity prevents confusion [45]. The value of studying the genetic control of this trait is reinforced because fertility over the whole mating period in spring increases with the proportion of spontaneously cyclic ewes before joining [18].

Thus, the purpose of our study was to estimate the genetic parameters of spontaneous spring ovulatory activity in the Mérinos d'Arles breed under the usual pastoral and transhumant management conditions of this breed in southeastern France.

\section{MATERIALS AND METHODS}

The Mérinos d'Arles ewes included in the experiment were animals of the experimental flock of the Domaine du Merle located in southeastern France $\left(43.5^{\circ} \mathrm{N}\right)$. The spontaneous ovulatory activity of the ewes was determined in spring, before the mating period, for 3 consecutive years (1995-1997).

\subsection{Management system}

In the past, the Mérinos d'Arles breed was used for wool production. It shows interesting aptitudes for adaptation to its environment and for aseasonality. These aptitudes are fully exploited in the breeding system in which it is used, i.e. with the main, or the only, joining season in spring, just before transhumance to the Alpine mountains in summer.

In the experimental flock of the Domaine du Merle, Mérinos d'Arles ewes are joined from 15 April to 15 June. For experimental purposes, a large number of the ewes were hormonally synchronised at mating. After transhumance, the 
ewes lambed in autumn. Lambing date and prolificacy were recorded. Fertility was expressed as a percentage and was computed as the number of ewes which lambed in autumn compared to the number of ewes recorded in April. Weaning took place in January. Hoggets were mated for the first time together with adult ewes when 18 months old. In this system, with one lambing per year, without 'cleanup' breeding in autumn, the out-of-season breeding ability of ewes in spring is of prime importance.

In this experimental flock, ewes were regularly weighed. The live weight of all ewes was recorded after weaning in January and just before the mating period in April.

\subsection{Blood sampling and hormone assay}

In order to specifically examine the spontaneous ovulatory activity, the ovulatory activity of ewes was studied before any reproduction event, i.e. before synchronisation and/or ram introduction. Two jugular blood samples per ewe were collected, at an interval of 8-10 days, during the first 2 weeks of April. Blood samples were centrifuged. The plasma progesterone concentration was assayed by radioimmunoassay using the technique described by Terqui and Thimonier [43]. Ewes with at least one sample in which progesterone was higher than $1 \mathrm{ng} / \mathrm{mL}$ were considered as being in ovulatory activity [44]. An ovulatory activity score of 1 was thus assigned for such ewes and a score of 0 otherwise. Most of the ovulatory cycles within the normal range duration were detected. However, this method did not allow the detection of short ovulatory cycles that may occur, especially at the onset of the breeding season.

\subsection{Animals and data sets}

The whole data set consisted of 1887 ovulatory activity records ( 0 or 1 ) measured in the first 2 weeks of April in the 3 consecutive years of the experiment. A total of 933 ewes, daughters of 176 rams, were included in the experiment. All the adult ewes in the flock were blood sampled. Ewes could be studied over 1 to 3 years as the result of the replacement of culled or removed animals. Thus, 241 ewes were not blood sampled in the 1st year (table I), whereas 413 ewes were not blood sampled in the last year. A total of 293, 326 and 314 ewes were blood sampled over 1, 2 and 3 years, respectively. The pedigree information of ewes was available over five generations. The total data set thus involved 3044 animals. A restricted data set was also considered. It involved only the first record of each ewe. Thus, this data set consisted of 933 records.

\subsection{Statistical and genetic analyses}

Potential factors affecting the variation of ovulatory activity, such as the year of test, the age of ewes, the date of previous lambing, the number of lambs suckled, the live weight of ewes at the weaning period and just before the mating period and its variation and the interaction between weight and age, were studied through an analysis of variance. Using the results of these studies, two fixed effects were defined for the genetic analysis. The first, which 
Table I. Number of ewes per sequence of cyclicity performance over 3 years.

\begin{tabular}{lrrrr}
\hline \multicolumn{2}{c}{ Year of measurement } & & \\
1995 & 1996 & 1997 & Number of ewes & Percentage \\
\hline$*$ & & 0 & 39 & 4.2 \\
& & 1 & 8 & 0.9 \\
& 0 & & 30 & 3.2 \\
& 0 & 0 & 108 & 11.6 \\
& 0 & 1 & 13 & 1.4 \\
& 1 & & 5 & 0.5 \\
& 1 & 0 & 16 & 1.7 \\
0 & 1 & 1 & 22 & 2.4 \\
0 & & & 152 & 16.3 \\
0 & 0 & & 142 & 10.3 \\
0 & 0 & 0 & 33 & 15.2 \\
0 & 0 & 1 & 19 & 3.5 \\
0 & 1 & & 28 & 2.0 \\
0 & 1 & 0 & 19 & 3.0 \\
1 & 1 & 1 & 59 & 2.0 \\
1 & & & 30 & 6.3 \\
1 & 0 & & 28 & 3.2 \\
1 & 0 & 0 & 18 & 3.0 \\
1 & 0 & 1 & 22 & 1.9 \\
1 & 1 & & 14 & 2.4 \\
1 & 1 & 0 & 32 & 1.5 \\
& 1 & 1 & 3.4 \\
\hline
\end{tabular}

*: no performance; 0 : no ovulatory activity; 1 : ovulatory activity.

represents the 'physiological status' had nine levels corresponding to hoggets (18 months), ewes without lambing in the previous autumn, and seven different ages (2.5-8.5 years old) for ewes dried-off in January. The second effect took into account the live weight just before the mating period through five classes defined with thresholds of $41,45,49$ and $55 \mathrm{~kg}$.

Ovulatory activity follows a discrete distribution ( 0 or 1$)$. Theoretically, the optimum method of analysis would have been to analyse it as categorical data using a non-linear model. Both linear and non-linear univariate mixed models were used in the study.

A linear model which considered the trait as continuous and normally distributed made it possible to take into account the largest quantity of pedigree information on the animals via an animal model. Such an approach is widely implemented in breeding programmes. The non-linear approach, which uses the threshold model developed by Gianola and Foulley [12] to analyse discrete traits, represents the method of choice to analyse ovulatory activity, but, as recommended for theoretical reasons, only a sire model was used.

The linear animal model was written as:

$$
\mathbf{y}=\mathbf{X b}+\mathbf{Z a}+\mathbf{W p}+\mathbf{e}
$$


where $\mathbf{y}$ is the ewes' performance vector, $\mathbf{b}$ is the fixed effect vector of age and/or physiological status and live weight just before the mating period, $\mathbf{a}$ is the random effect vector of animals, $\mathbf{p}$ is the random effect vector associated with the ewe (the permanent effect was included to take into account repeated records), $\mathbf{e}$ is the random residual effect vector and $\mathbf{X}, \mathbf{Z}$ and $\mathbf{W}$ are the incidence matrices.

Random factors are normally distributed with the following expectation and variance-covariance structure:

$$
\left(\begin{array}{l}
\mathbf{a} \\
\mathbf{p} \\
\mathbf{e}
\end{array}\right) \sim \mathrm{N}\left[\left(\begin{array}{l}
\mathbf{0} \\
\mathbf{0} \\
\mathbf{0}
\end{array}\right),\left(\begin{array}{ccc}
\mathbf{A} \sigma_{\mathrm{a}}^{2} & \mathbf{0} & \mathbf{0} \\
\mathbf{0} & \mathbf{I} \sigma_{\mathrm{p}}^{2} & \mathbf{0} \\
\mathbf{0} & \mathbf{0} & \mathbf{I} \sigma_{\mathrm{e}}^{2}
\end{array}\right)\right]
$$

where $\mathbf{A}$ is the numerator relationship matrix including 3044 animals; $\sigma_{\mathrm{a}}^{2}, \sigma_{\mathrm{p}}^{2}$ and $\sigma_{\mathrm{e}}^{2}$ are the animal, permanent effect and residual variances, respectively.

Genetic parameters were estimated with a single trait restricted maximum likelihood (REML) analysis fitted to the linear animal model described in equation (1). The variance component estimation (VCE) 3.2 programme written by Groenveld [13] was used. Heritability $\left(h^{2}\right)$ and repeatability $(r)$ were obtained from the estimated variance components as follows:

$$
h^{2}=\frac{\sigma_{\mathrm{a}}^{2}}{\sigma_{\mathrm{a}}^{2}+\sigma_{\mathrm{p}}^{2}+\sigma_{\mathrm{e}}} \text { and } r=\frac{\sigma_{\mathrm{a}}^{2}+\sigma_{\mathrm{p}}^{2}}{\sigma_{\mathrm{a}}^{2}+\sigma_{\mathrm{p}}^{2}+\sigma_{\mathrm{e}}^{2}}
$$

The best linear unbiased predictor (BLUP) for the fixed and the random effects of equation (1) was computed. It used the variance components from the REML analysis.

The threshold model is based on the assumption that the observed values ( 0 or 1 in this study) are related to an underlying Gaussian variable, usually called liability. The model used for liability was:

$$
\ell=\mathbf{X} \mathbf{b}+\mathbf{Z}^{*} \mathbf{s}+\mathbf{e}^{*}
$$

where $\ell$ is the liability vector, $\mathbf{b}$ is the fixed effect vector, $\mathbf{s}$ is the random effect vector of sires, $\mathbf{e}^{*}$ is the random residual effect vector and $\mathbf{X}$ and $\mathbf{Z}^{*}$ are the incidence matrices. The expectation and variance-covariance structure was as follows:

$$
\left(\begin{array}{c}
\mathbf{s} \\
\mathbf{e}^{*}
\end{array}\right) \sim \mathrm{N}\left[\left(\begin{array}{l}
\mathbf{0} \\
\mathbf{0}
\end{array}\right),\left(\begin{array}{cc}
\mathbf{A}_{\mathrm{s}} \sigma_{\mathrm{s}}^{2} & \mathbf{0} \\
\mathbf{0} & \mathbf{I}
\end{array}\right)\right]
$$

where $\mathbf{A}_{\mathrm{s}}$ is the numerator relationship restricted to the sires including 652 animals and $\sigma_{\mathrm{s}}^{2}$ is the sire variance.

The threshold model was only used to analyse the restricted data set. Estimates of the effects of the model and of variance components were obtained as proposed by Gianola and Foulley [12]. With such a model, heritability computed for liability $\left(h_{\ell}^{2}\right)$ was obtained as follows:

$$
h_{\ell}^{2}=\frac{4 \sigma_{\mathrm{s}}^{2}}{\sigma_{\mathrm{s}}^{2}+1}
$$


Heritabilities obtained on the observed scale and on the underlying scale may be related using the expression proposed by Robertson and Lerner [38]:

$$
h_{\ell}^{2}=\frac{h^{2} z^{2}}{p(1-p)}
$$

where $z$ is the value of the density of the underlying normal distribution at the threshold point corresponding to $p, p$ being the mean percentage of ewes in ovulatory activity in the flock.

\section{RESULTS}

\subsection{Phenotypic means}

For the 3 years (table II), $27.9 \%$ of the ewes presented spontaneous ovulatory activity in April. Percentages were very similar from one year of experiment to another. Among the 314 ewes measured over 3 consecutive years (table I), 142 ewes were never ovulatory and 32 were always in ovulatory activity in spring. The weight just before the mating period (table II) was $47.0 \mathrm{~kg}$. It varied from 46.2 in 1996 to 48.5 in 1997.

Table II. Phenotypic means on live weight and reproductive performance.

\begin{tabular}{lcccc}
\hline & 1995 & 1996 & 1997 & Overall mean \\
\hline $\begin{array}{l}\text { \% cycling } \\
\text { Live weight just }\end{array}$ & 29.4 & 26.3 & 27.9 & 27.9 \\
$\begin{array}{l}\text { before the mating } \\
\text { period (kg) }\end{array}$ & 46.8 & 46.2 & 48.5 & 47.0 \\
(SD) & $(5.6)$ & $(5.9)$ & $(5.6)$ & $(5.7)$ \\
Fertility (\%) & 96.7 & 97.7 & 84.3 & 93.1 \\
Prolificacy & 138 & 136 & 138 & 137 \\
Date of lambing & 10 Oct. 95 & 2 Oct. 96 & 14 Oct. 97 & 6 Oct. \\
\hline
\end{tabular}

SD: standard deviation.

\subsection{Factors of variation}

The change in live weight between the drying-off in January and the weighing period in April just before mating, the interaction between live weight and age, the number of suckled lambs or the lambing date for ewes with lambing in the previous autumn were found to have no significant effect on ovulatory activity in spring. As a consequence, only live weight just before the mating period, the previous physiological status and the age for ewes dried-off in January were taken into account in the analysis. The BLUP estimates for fixed effects adjusted to the phenotypic mean are shown in figures 1 and 2. The effect of age on ovulatory activity (figure 1) was positive, especially for young ewes. 


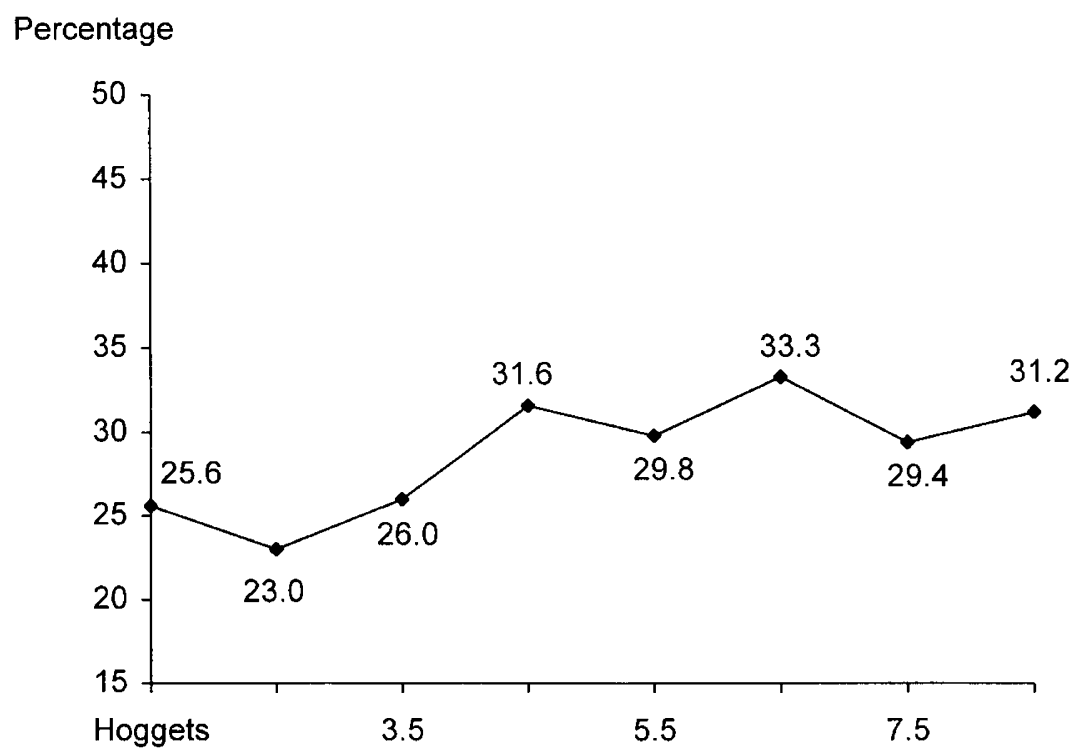

Age (year) - physiological status of ewes

Figure 1. Best linear unbiased estimates for the effect of age-physiological status of ewes on spring spontaneous ovulatory activity (adjusted to the phenotypic mean) using a linear animal model.

\section{Percentage}

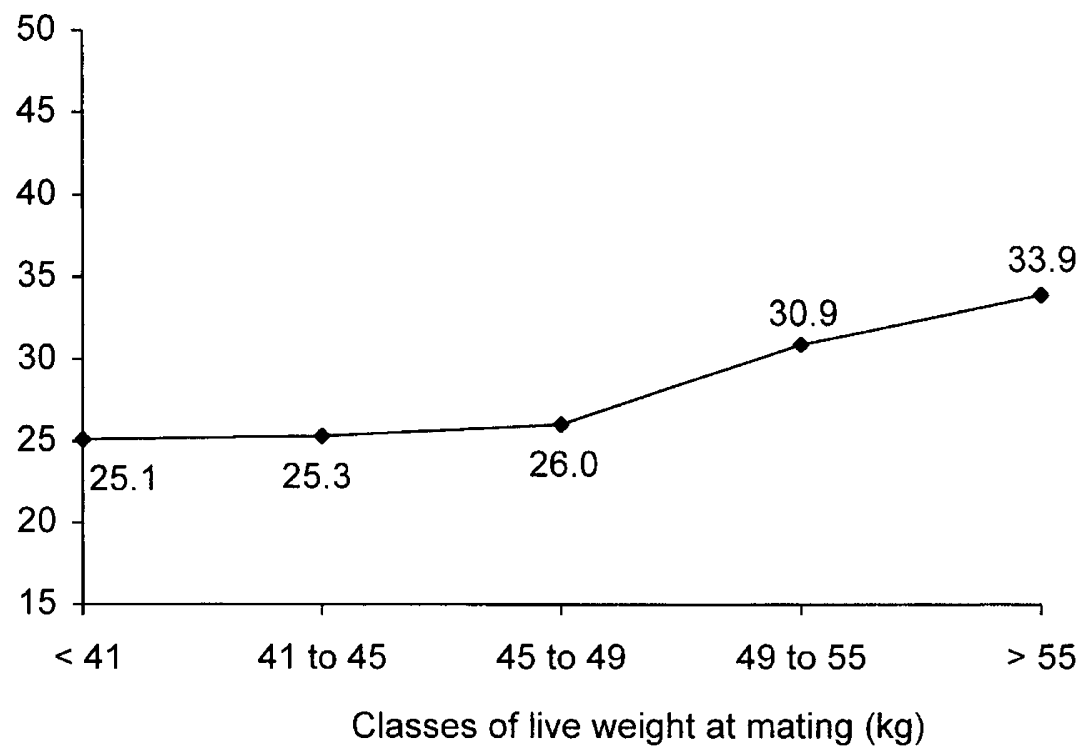

Figure 2. Best linear unbiased estimates for the effect of live weight at mating on spring spontaneous ovulatory activity (adjusted to the phenotypic mean) using a linear animal model. 
An increase of about 8-9\% in the ovulatory activity was observed in 2.5- to 4.5-year-old ewes. After 4.5 years of age, there was no significant difference between age levels. The estimated effect of live weight just before the mating period on ovulatory activity (figure 2) showed an almost null effect below $49 \mathrm{~kg}$ and a marked positive effect for a higher weight. A difference of about $9 \%$ in ovulatory activity was observed between extreme classes. Estimates of fixed effects with linear and threshold models were consistent.

Age and live weight were strongly correlated factors. Although the interaction between age and live weight was not statistically significant, it was nevertheless studied. The joint effects of age and weight are shown in figure 3; for the sake of simplicity, only classes of age 2.5 and 3.5 are shown. Ovulatory activity increased with live weight. For each class, a threshold effect, characterised by a clear increase, was observed ( 41 to 45 and 45 to 49 for ages 2.5 and 3.5, respectively).

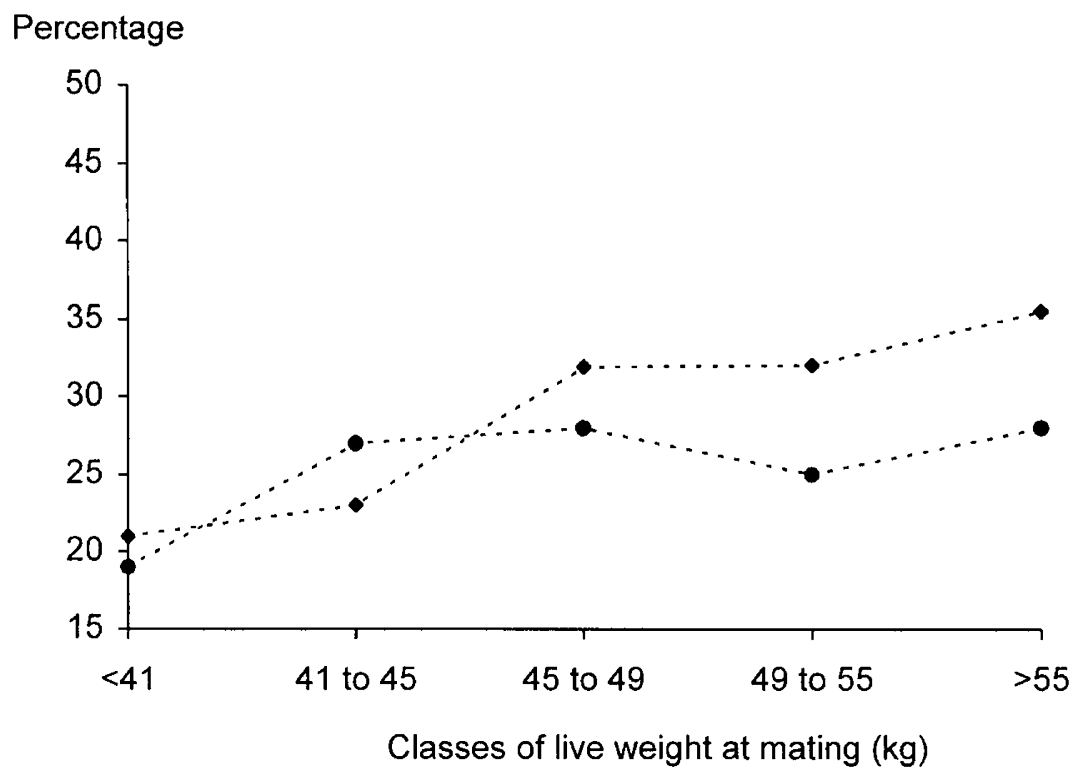

Figure 3. Least squares mean estimates of spring spontaneous ovulatory activity with regard to live weight at mating of ewes and age: $2.5(-\bullet-)$ and $3.5(--)$ years.

\subsection{Genetic analysis}

The heritability of spontaneous spring ovulatory activity estimated with a linear animal model in Mérinos d'Arles ewes was $h^{2}=0.20$ with a standard error of 0.04 (table $I I I)$. The estimate of repeatability was $r=0.30$ with a standard error of 0.07 . Heritability in the threshold sire model was 0.37 . The approximate value obtained with equation (7) was 0.36 . 
Table III. Estimates of heritability and repeatability of spontaneous spring ovulatory activity in Mérinos d'Arles breed.

\begin{tabular}{|c|c|c|c|c|c|}
\hline Models & & Random effects & Data sets & Heritability & Repeatability \\
\hline Animal model & $\mathrm{L}^{*}$ & $\begin{array}{c}\text { Animal }+ \\
\text { permanent }\end{array}$ & 1887 records & $\begin{array}{c}0.20 \\
(0.04)^{\mathrm{a}}\end{array}$ & $\begin{array}{c}0.30 \\
(0.07)\end{array}$ \\
\hline Sire model & $\mathrm{T}$ & Sire & 933 records & 0.37 & - \\
\hline
\end{tabular}

L: linear; T: threshold; a: standard error.

\subsection{Relationship with reproductive performance}

In the experimental flock the ewes were involved in several experiments. Thus, during the 2 months of the mating period, they received various breeding treatments according to the needs of each experiment. Despite this heterogeneity, fertility, prolificacy and lambing date were calculated. Results over the whole mating period were $93.1 \%, 137$ and 6th October, respectively. Slight variations between years existed (except for fertility in 1997). With such a mixture of management system, no relationship was found between out-of-season ovulatory activity and fertility, prolificacy or lambing date.

\section{DISCUSSION AND CONCLUSION}

In this study, the previous physiological status, live weight and age of ewes were found to have significant effects on spontaneous ovulatory activity in April. Ovulatory activity increased with live weight and age. The youngest females included in the analysis were 18 months old. Thus, performance was independent of any influence of puberty. Adult ewes (with at least one previous lambing) and hoggets were consequently analysed together. In spite of a slight confounding between age and physiological status effects, a specific influence on natural ovulatory activity was found for both effects. The date of lambing in the previous autumn was found to have no influence on ovulatory activity in spring. However, uterine involution is complete after 28 days [46] and the conception rate is not down to standard after 40 to 50 days post-partum [4, $19,42]$. These results explain why a post-partum interval of about 8 months (which corresponds to a one lambing per year reproduction system) cannot have an effect on ovulatory activity. In contrast, shorter intervals, as studied by Dzabirski and Notter [7] when comparing autumn lambing with winter lambing, showed a clear positive effect of time since lambing.

In a linear animal model, heritability and repeatability were estimated at 0.20 and 0.30 , respectively. These values are quite high and the efficiency of selection for spring breeding ability is supported by these results. Even if, in the present study, the exact relation of the period of measurements (April) to the whole natural breeding period is unknown, the above values are in the same range as those obtained in various studies. Heritability estimates for the date of onset, the date of cessation or the duration of the breeding season have been found to be between 0.20 and 0.35 [8,33-35]. These values are slightly higher than those obtained for fertility (0.13) in fall lambing by Shelton 
and Menzies [39], Smith et al. [40] and Notter et al. [25], but the latter trait may be considered as a more complex trait in comparison to breeding season characteristics. In the Mérinos d'Arles breed, Razungles et al. [36] obtained a similar heritability $(0.17)$ for fertility in spring, but lambings were from both ewes with spontaneous ovarian activity and ewes ovulating in response to ram introduction.

Heritability was consistently larger with the threshold sire model than with the linear animal model. Gianola [11] showed that this is an expected result when comparing both theoretical methods when the layout is not highly unbalanced. The increase was in accordance with that expected when using the approach of Robertson and Lerner [38]. This trend was also found experimentally when estimating genetic parameters for reproductive traits in sheep [10, 21, 29]. Except for Meijering and Gianola [22] in some particular unbalanced situations of a simulation study, the efficiency of selection, however, is usually unchanged when using a linear method of sire evaluation or the threshold method.

In the present experiment, after the experimental period, some ewes were hormonally synchronised at mating and the expression of fertility did not result from the natural out-of-season breeding ability. Moreover, even in the case of natural mating, the ewes involved in different experiments had various breeding treatments. It is then not surprising to find no relation between spontaneous ovulatory activity in early spring and reproductive parameters corresponding to the following mating period. Estimates of genetic relationships between characteristics of seasonality and prolificacy are quite scarce and will require further studies to be performed. Purser [33] found no genetic relationships between the date of onset of the breeding season and the litter size, whereas Owen et al. [31] found a positive genetic correlation. Dzabirski and Notter [7] reported a lower prolificacy for ewes with spontaneous ovulatory activity in spring probably due to the interaction with seasonal variations in the ovulation rate $[16]$.

In this study, the spring ovulatory activity just before mating was the criterion used to measure the out-of-season breeding ability of ewes. A more detailed analysis of the ovulatory activity of ewes from January until the mating period has to be performed to test whether the spring activity corresponds to an end, an onset of the breeding season, a sporadic activity or a continuous activity of aseasonal ewes. With a clear objective to select truly aseasonal ewes, measuring ovulatory activity in the fully out-of-season period appears to be appropriate. Selection based on later or earlier tests could only induce an advanced or a later breeding season, and thus a shifted breeding season which is easier to obtain than a permanent sexual activity [24]. Nevertheless, even with spring testing, there is a risk of selecting either ewes with only a sporadic activity preceded and followed by anestrus periods as observed by Thimonier and Mauléon [45] or ewes with a completely changed breeding season without any increase in the duration. In selection experiments, Dzabirski and Notter [7] showed an advanced date of lambing in autumn for ewes with spontaneous ovulatory activity in spring in comparison to ewes responding to ram introduction. When selecting for fall lambing fertility, Notter et al. [25] mentioned a correlated positive response in the extension of the breeding season. 
Estimated genetic parameters are high enough to allow efficient selection on the studied trait. Estimates were based on a large number of records. This guarantees good reliability of the results. Nevertheless, more information on the real efficiency of such selection and its consequences for reproductive performance is necessary.

Moreover, further physiological and genetic studies on the endocrine mechanisms controlling seasonal breeding are essential to better control the consequences of selection and to improve its efficiency. The assumption of an overall and common factor controlling seasonal variations is supported by various studies. For instance, correlated response in changes in seasonal breeding were observed by Haley et al. [15] and by Montgomery and Hawker [23] when selecting for out-of-season testis size and wool growth, respectively. A candidate overall factor could be melatonin, the hormonal messenger by which animals perceive night duration and then seasonal variations [20]. In addition, Zarazaga et al. [47] showed that variability in the night-time melatonin plasma concentration was under strong genetic control. Studies relating such melatonin characteristics to variations in classical seasonal breeding traits should be performed.

\section{ACKNOWLEDGEMENTS}

The authors wish to thank the staff in charge of the Mérinos d'Arles flock in Le Merle, especially C. Lefèvre, P. Bosc, M. Vincent and M. Maillon, the RIA laboratory in Nouzilly for performing the progesterone assays and M. San Cristobal-Gaudy for her computational help. An Inra programme (ADELE-H) partly supported this study.

\section{REFERENCES}

[1] Bodin L., Drion P.V., Remy B., Brice G., Cognié Y., Beckers J.F., AntiPMSG antibody levels in sheep subjected annually to oestrus synchronisation, Reprod. Nutr. Dev. 37 (1997) 651-660.

[2] Chemineau P., Malpaux B., Pelletier J., Leboeuf B., Delgadillo J.A., Deletang F., Pobel T., Brice G., Emploi des implants de mélatonine et des traitements photopériodiques pour maîtriser la reproduction saisonnière chez les ovins et les caprins, Inra Prod. Anim. 9 (1996) 45-60.

[3] Cognié Y., Nouvelles méthodes utilisées pour améliorer les performances de reproduction chez les ovins, Inra Prod. Anim. 1 (1988) 83-92.

[4] Dufour J.J., Effects of season on postpartum characteristics of sheep being selected for year-round breeding and on puberty of their female progeny, Can. J. Anim. Sci. 55 (1975) 487-492.

[5] Dufour J.J., Fahmy M.H., Adelakoun V., Matton P., Ovarian and oestrous activity throughout the year in pregnant and nonpregnant ewes selected for extended breeding season, Can. J. Anim. Sci. 62 (1982) 1101-1108.

[6] Dyrmundsson O.R., Adalsteinsson S., Coat-color gene suppresses sexual activity in Icelandic sheep, J. Hered. 71 (1980) 363-364.

[7] Dzabirski V., Notter D.R., Effects of breed and time since lambing on spring oestrous activity in mature ewes, Anim. Reprod. Sci. 19 (1989) 99-108.

[8] Fahmy M.H., Genetic parameters of date of lambing in 'DLS' sheep, in: Barton R.A., Smith W.C. (Eds.), Proc. World Congr. on Sheep and Beef Cattle Breeding, Palmerston North, New Zealand, 1982, pp. 401-404. 
[9] Fahmy M.H., Dufour J.J., The breeding season and ovulation rate of DLS ewes as determined by laparoscopy, Can. J. Anim. Sci. 66 (1986) 297-301.

[10] Gates P.J., Urioste J.I., Heritability and sire genetic trend for litter size in Swedish sheep estimated with linear and threshold models, Acta Agric. Scand. 45 (1995) 228-235.

[11] Gianola D., Theory and analyses of threshold characters, J. Anim. Sci. 54 (1982) 1079-1096.

[12] Gianola D., Foulley J.L., Sire evaluation for ordered categorical data with a threshold model, Genet. Sel. Evol. 15 (1983) 201-224.

[13] Groeneveld E. (Ed.), REML VCE - a multivariate multimodel restricted maximum likelihood (co)variance component estimation package, Version 3.2, User's Guide, 1996.

[14] Hafez E.S.E., Studies on the breeding season and reproduction in the ewe, J. Agric. Sci. (Camb.) 42 (1952) 189-265.

[15] Haley C.S., Lee G.J., Ritchie M., Land R.B., Direct response in males and correlated responses for reproduction in females to selection for testicular size adjusted for body weight in young male lambs, J. Reprod. Fertil. 89 (1990) 383-396.

[16] Hall D.G., Fogarty N.M., Gilmour A.R., Seasonality of ovulation and oestrus, and the ram effect in Poll Dorset ewes, Theriogenology 25 (1986) 455-461.

[17] Hanrahan J.P., Genetic variation in seasonal reproduction in sheep, in: 38th EAAP Annu. Meeting, Lisbon, Portugal, 28 September-1 October 1987, 14 p.

[18] Khaldi G., Variations saisonnières de l'activité ovarienne, du comportement d'œstrus et de la durée de l'anœstrus postpartum des femelles ovines de race Barbarine : influence du niveau alimentaire et de la présence du mâle, thèse, Université de Montpellier, France, 1984, 168 p.

[19] Land R.B., The incidence of oestrus during lactation in Finnish Landrace, Dorset Horn and Finn-Dorset sheep, J. Reprod. Fertil. 24 (1971) 345-352.

[20] Malpaux B., Viguié C., Skinner D.C., Thiéry J.C., Pelletier J., Chemineau P., Seasonal breeding in sheep: mechanism of action of melatonin, Anim. Reprod. Sci. 42 (1996) 109-117.

[21] Matos C.A.P., Thomas D.L., Gianola R., Tempelman J., Young L.D., Genetic analysis of discrete reproductive traits in sheep using linear and non-linear models: estimation of genetic parameters, J. Anim. Sci. 75 (1997) 76-87.

[22] Meijering A., Gianola D., Linear versus non-linear methods of sire evaluation for categorical traits: a simulation study, Genet. Sel. Evol. 17 (1985) 115-132.

[23] Montgomery G.W., Hawker H., Seasonal reproduction in ewes selected on seasonal changes in wool growth, J. Reprod. Fertil. 79 (1987) 207-213.

[24] Notter D.R., Manipulation of the breeding season by genetic means, in: Burfening P.J., Gabina D. (Eds.), US-Spain Seminar on Sheep Breeding, Zaragoza, Spain, 10-15 November, 1986, $22 \mathrm{p}$.

[25] Notter D.R., Al-Shorepy S.A., Vincent J.N., McQuown E.C., Selection to improve fertility in fall lambing, in: 6th WCGALP, Armidale, Australia, 11-16 January, 1998, pp. 43-46.

[26] Nugent R.A., Notter D.R., Effect of cohabitation with White-faced ewes on oestrous activity of Hampshire and Suffolk ewes exposed to rams in June, J. Anim. Sci. 68 (1990) 1513-1519.

[27] Oldham C.M., Stimulation of ovulation in seasonally or lactationally anovular ewes by rams, in: Proc. Aust. Soc. Anim. Prod. 13 (1980) 73-86.

[28] Oldham C.M., Cognié Y., Do ewes continue to cycle after teasing? in: Proc. Aust. Soc. Anim. Prod. 13 (1980) 82-85.

[29] Olesen I., Perez-Enciso M., Gianola D., Thomas D.L., A comparison of normal and nonnormal mixed models for number of lambs born in Norwegian sheep, J. Anim. Sci. 72 (1994) 1166-1173. 
[30] Ortavant R., Pelletier J., Ravault J.P., Thimonier J., Volland-Nail P., Photoperiod: main proximal and distal factor of the circannual cycle of reproduction in farm animals, Oxford Rev. Reprod. Biol. 7 (1985) 305-345.

[31] Owen J.B., Crees S.R.E., Williams J.C., Prolificacy and 50-day lamb weight of ewes in the Cambridge sheep breed, Anim. Prod. 42 (1986) 355-363.

[32] Pearce D.T., Oldham C.M., The ram effect, its mechanism and application to the management of sheep, in: Lindsay D.R., Pearce D.T. (Eds.), Reproduction in Sheep, Australian Academy of Science, Canberra, 1984, pp. 26-34.

[33] Purser A.F., Variations in date of first oestrus among Welsh Mountain ewes, in: Proc. Br. Soc. Anim. Prod. 133 (1972) (abstr).

[34] Quirke J.F., Hanrahan J.P., Breed differences in the breeding season in sheep, Curr. Top. Vet. Med. Anim. Sci. 31 (1985) 29-43.

[35] Quirke J.F., Hanrahan J.P., Loughnane W., Triggs R., Components of the breeding and non-breeding seasons in sheep: breed effects and repeatability, Irish $\mathrm{J}$. Agric. Res. 25 (1986) 167-172.

[36] Razungles J., Ricordeau G., Tchamitchian L., Prud'hon M., Variations génétiques de la fertilité des brebis Mérinos d'Arles, Ann. Genet. Sel. Anim. 7 (1975) 409-419.

[37] Ricordeau G., Selection for reduced seasonality and post-partum anestrus, in: 2nd WCGALP, Madrid, Spain, 1982, pp. 338-347.

[38] Robertson A., Lerner I.M., The heritability of all-or-none traits: viability of poultry, Genetics 34 (1949) 395-411.

[39] Shelton M., Menzies J.W., Repeatability and heritability of components of reproductive efficiency in fine-wool sheep, J. Anim. Sci. 30 (1970) 1-5.

[40] Smith J.F., Johnson D.L., Reid T.C., Genetic parameters and performance of flocks selected for advanced lambing date, in: Proc. New Zealand Soc. Anim. Prod. 52 (1992) 50 (abstr).

[41] Tchamitchian L., Choix du moment et du rythme de reproduction, Possibilités de la génétique, in: Proc. of 3rd World Congr. on Sheep and Beef Cattle Breeding, Paris, 19-23 June, Inra Publ., Paris, 1988, pp. 529-546.

[42] Tchamitchian L., Ricordeau G, Lefèvre C, Desvignes A., Observations sur l'anœstrus postpartum des brebis Romanov après un agnelage en saison sexuelle, Ann. Zootech. 22 (1973) 295-301.

[43] Terqui M., Thimonier J., Nouvelle méthode radio-immunologique rapide pour l'estimation du niveau de progestérone plasmatique. Application pour le diagnostic précoce de gestation chez la brebis et la chèvre, C.R. Acad. Sci. Paris, série D 279 (1974) 1109-1112.

[44] Thimonier J., Contrôle photopériodique de l'activité ovulatoire chez la brebis. Existences de rythmes endogènes, thèse, Université de Tours, France, 1989, 112 p.

[45] Thimonier J., Mauléon P., Variations saisonnières du comportement d'œstrus et des activités ovariennes et hypophysaires chez les ovins, Ann. Biol. Anim. Bioch. Biophys. 9 (1969) 233-250.

[46] Van Niekerk C.H., Limitations to female reproductive efficiency, in: Tomes G.J., Robertson D.E., Lightfoot R.J. (Eds.), Sheep Breeding, West Australian Institute of Technology, 1976, pp. 303-314.

[47] Zarazaga L.A., Malpaux B., Bodin L., Chemineau P., The large variability in melatonin blood levels in ewes is under strong genetic influence, Am. J. Physiol. 274 (1998) 607-610. 